\title{
Case Study Regarding the Evaluation of Carbon Dioxide in Modular Tiny Houses
}

\author{
Studiu de caz privind evaluarea dioxidului de carbon în casele mici \\ modulare
}

\author{
Carmen Mârza $^{1}$, Georgiana Corsiuc ${ }^{1}$, Dana Adriana Iluţiu-Varvara ${ }^{1}$ \\ ${ }^{1}$ Technical University of Cluj-Napoca, Faculty of Building Services Engineering \\ 21 Decembrie 1989 Street, 400604, Cluj-Napoca, Romania \\ E-mail:Carmen.Marza@insta.utcluj.ro,Georgiana.Corsiuc@gmail.com,Dana.Varvara@gmail.com
}

DOI: $10.37789 /$ rjce.2022.13.1.1

\begin{abstract}
Indoor air quality plays an important role both in the well-being of occupants as well in the efficiency of the performed activities - either they are of an intellectual or physical nature. In this paper, after a general presentation of the main pollutants of indoor air environment, the authors have proposed a study, based on experimental measurements, about the concentration of carbon dioxide in a tiny house, that is part of a larger Start Up Nation project, which proposed several types of prefabricated modular constructionst.
\end{abstract}

Key words: Air Quality, Modular Buildings, Pollutants, Carbon Dioxide

\section{Introduction}

After 1989, there were several currents in our country regarding the construction of residential buildings. In a first stage, as an anti-reaction to the fact that most people lived in modest size apartments, in residential blocks built according to standardized projects, those with financial possibilities opted for single-family buildings, often characterized by excess space. Over time, the disadvantages of living in such big houses have been found, which are mainly aimed at high maintenance costs and energy consumption. Multifamily buildings were then built, also with generous spaces. With the change of generations and the migration of the rural population in the urban area - as source of jobs, the need for new living spaces appeared. Thus, the housing fund has become very different, to satisfy customers with various material possibilities.

A solution that has timidly started to develop in the last years, has been modular houses, which responds to the alert lifestyle, specific to the period we are going through. They are well suited as small dwellings, but can be extended to various 
destinations, such as holiday homes, social houses that can be fast build in disaster areas. In the unfortunate context of the pandemic caused by Sars Cov 19, in which home office was practiced and families were isolated, frequently appeared the phenomenon to acquire a plot of land near urban areas or in remote areas, on which one can install this type of construction, to which the authorization part is easier.

Due to their small size, they can be transported, without major efforts, by road or rail - if the infrastructure allows [1]. Modular constructions represent an efficient and economical alternative to build, in which the beneficiary of the house can have the certainty of a quality construction, in a relatively short time, made in optimized conditions by specialists in the field, at a mutually agreed price, without further adjustments [1]. At the same time, are characterized by low energy requirement both in the execution and in exploitation phase.

A challenge that these houses pose to specialists in the field of architecture, as well to those in the field of civil engineering and building services, is to ensure a living climate that meets the requirements of normative, to ensure the well-being of occupants. One refers to the indoor environmental quality, which is a more complex concept, respectively to the indoor air quality.

In this paper, the authors' attention focuses on a study on indoor air quality, abbreviated IAQ. After a presentation of the main indoor air pollutants and the main measures for their elimination or reduction, a set of measurements were performed to verify whether, in the case of small volumes of air - as is the case of these modular constructions, an appropriate level of $\mathrm{CO}_{2}$ is maintained, which does not adversely affect the health of the occupants.

\section{Aspects regarding indoor air quality}

If outdoor air quality has been in the public attention for several decades, with the primary objective of monitoring greenhouse gases, indoor air quality in residential buildings has been less approached. IAQ has been studied primarily in spaces with special destinations, such as chemical laboratories, pharmaceutical laboratories, hospitals - surgical blocks, workshops in which they work with volatile or semivolatile substances, etc.

Nowadays, due to the fact that, on average, people spend $60-90 \%$ of their time indoors - houses, workplaces, commercial spaces, performance halls, sports halls etc., IAQ also becomes extremely important.

Gases, vapors and odors arise in residential buildings through the release of the human body (carbon dioxide, ammonia, methane, acids, etc.), emanations from furniture, carpets, paintings, paints and other building materials (formaldehyde), by combustion and heating processes (carbon oxide, fuel vapors), by cleaning, by infiltration of external air - polluted with exhaust gases or coming from industrial areas, by preparing meals in the kitchens, from baths, from chemical reactions produced by molds, fungi, or other decaying products [2], [3], [4]. 
Case Study Regarding the Evaluation of Carbon Dioxide in Modular Tiny Houses

In the indoor air one can find up to 8000 harmful compounds, some from humans, others from building materials and/or from outside. Indoor air pollutants can be grouped, as follows [2], [5]:

> Pollutants from the outside air, which enter either with the occupants, or through natural or mechanical ventilation, without a proper filtration;

$>$ Pollutants that are released into the interior space:

- Biological pollutants - resulted from the releases of the human body $\left(\mathrm{CO}_{2}\right)$, respectively bacteria, viruses, pet hair, pollen, pests; also, here one can categorized mites, mold, generated by wet, unhealthy structure of the constructure or by maintaining a high level of humidity;

- Volatile organic compounds (VOC) or semi-volatile (SVOC) - emitted from various household products, such as paints, adhesives, sprays, at certain temperatures;

- Particulate Matter (PM) or fine particles (PM2.5) - Emitted by stoves, heaters, fireplaces where the combustion of fuel takes place;

- Carbon monoxide (CO) - Emitted from stoves, heaters, tobacco smoke, burning candles;

- Nitrogen dioxide $\left(\mathrm{NO}_{2}\right)$ - Emitted from improperly ventilated stoves, cigarette smoke;

- Ozone - if the upper layer of ozone in the atmosphere is beneficial because it provides protection against ultraviolet radiation, at ground level it is an odorless pollutant, with negative effects on the airways and some household items (books, furniture, fabrics); it can also raise the level of other contaminants; ozone is formed as a result of chemical reactions between nitrogen oxides and VOCs, in the presence of light;

- Radon - odorless and colorless radioactive gas formed naturally by the decomposition of uranium that can be found in certain soils; it can penetrate underground buildings, through foundations, basements or cracks;

- Cigarette smoke, which will be further develop.

A very particular pollution is that due to cigarette smoke which contains a significant number of particles, both solid and gaseous, 1 gram of tobacco producing 0.5 liters of smoke. A single cigarette releases $70 \mathrm{mg}$ of CO [6]. In order not to exceed the limit value of $5 \mathrm{ppm} \mathrm{CO}$, it is necessary to ensure a volume of fresh air of $12.5 \mathrm{~m}^{3} / \mathrm{h}$ (knowing that $1 \mathrm{mg} / \mathrm{m}^{3} \mathrm{CO}=0.9 \mathrm{ppm}$ ) [6]. Non-smokers (especially children and sick people) suffer from mucosal and respiratory tract irritations. The most harmful compounds are carbon monoxide and nicotine, which, even in low concentrations, can cause nausea and the debut of intoxication to sensitive individuals. In public places due to the controversial anti-smoking law, in many countries, this type of pollution has been eliminated. But this restriction does not apply to residential buildings and therefore specialists must inform about the negative effects on the occupants.

All these pollutants have negative effects on human health, such as: respiratory problems, the disease known as "building illness syndrome", asthma, mucosal 
irritations, headaches, nausea, promote lung cancer and in extreme cases can cause death, such as the case of $\mathrm{CO}$ intoxication. It also decreases the body's immunity.

In other words, it is essential for a healthy life to monitor these contaminants which, in addition to the suffering of people who are affected by their negative effects, ultimately turn into high costs for the health system.

Measures to eliminate these pollutants are numerous and depend on the type of pollutant.

Thus for those coming from the outside air one can mention [2], [7]:

$\checkmark$ the use of carpets / rugs at the entrance of the houses;

$\checkmark$ careful placement of inlets for the supply of fresh air and filtered air;

$\checkmark$ proper ventilation of the indoors so as to ensure the air exchange rate, without excess, in order to not increase energy consumption;

$\checkmark$ protection against pests;

$\checkmark$ maintaining adequate pressure connections between spaces with various destinations;

$\checkmark$ ensuring the conditions for a proper humidity of the envelope both in the construction phase and in the operation phase of the house.

Regarding the measures that can be taken to eliminate or maintain below the limited values of the indoor pollutants, one can mention [2], [5], [7]:

$\checkmark$ the use of a ventilation or air conditioning system adequate to the space and the demands of the residents;

$\checkmark$ careful selection of the construction materials;

$\checkmark$ elimination as much as possible, respectively limiting the materials that emit VOCs, SVOCs or in case their use is necessary, ensuring a volume of fresh air to counteract their negative effects;

$\checkmark$ keeping a humidity level in the interval imposed by the comfort standards (guidance, relative humidity $\varphi=35-70 \%$ );

$\checkmark$ elimination of smoking inside of dwellings;

$\checkmark$ awareness of healthy cooking and elimination of fried foods in kitchens, respectively the use of hoods to locally extract pollutants, like smoke, chemicals and hazardous particles (PM 10, PM 2.5);

$\checkmark$ maintaining the proper cleaning and hygiene of the spaces, in parallel with the selection of cleaning products;

$\checkmark$ knowledge of reactions regarding air chemistry and reactions that can lead to toxic elements;

$\checkmark$ use of houseplants;

$\checkmark$ attention in the choice of pets;

$\checkmark$ use of air purifiers.

As mentioned above, it has been found that there are a multitude of pollutants, which makes it impossible to monitor quantitatively and qualitatively each of them. In this context, Professor Fanger proposed that all these compounds to be measured by a single parameter: odor, for which purpose he also defined the unit of measurement called OLF. The principle of the method is, in fact, to accept the hypothesis that, by 
eliminating the odor through ventilation, will simultaneously eliminate all other undetectable pollutants at permissible concentrations values [8].

This method was not unanimously accepted, so it remains as a possibility to follow the indoor air quality the performing of measurements for certain types of pollutants considered essential.

\section{Case study}

The concentration of $\mathrm{CO}_{2}$ results mainly from expiration, as well as from combustion, respectively other processes that can take place in the residence.

The $\mathrm{CO}_{2}$ flow resulting from expiration can be calculated using the equation [9], [10]:

where,

$$
\mathrm{G}=4 \cdot 10^{-5} \mathrm{M} \cdot \mathrm{S}_{\mathrm{c}} \quad(1)
$$

$\mathrm{G}-\mathrm{CO}_{2}$ flow from expiration $[1 / \mathrm{s}]$;

M- specific metabolism $\left[\mathrm{W} / \mathrm{m}^{2}\right]$;

$\mathrm{S}_{\mathrm{c}}$ - the area of the body $\left[\mathrm{m}^{2}\right]$, which can be consider approximately $1.8 \mathrm{~m}^{2}$, respectively can be calculated according to du Bois's formula [11]:

$$
\mathrm{S}_{\mathrm{c}}=0.203 \cdot 10^{-4} \mathrm{~m}^{0.425} \mathrm{~h}^{0.725}
$$

where,

$\mathrm{m}$ - the weight of the person $[\mathrm{Kg}]$;

$\mathrm{h}$ - the height of the person [m].

But, given that $\mathrm{CO}_{2}$ production is not solely due to expiration, a rigorous method for monitoring it is the effective measurements.

The amount of $\mathrm{CO}_{2}$ is expressed in either $[\mathrm{ppm}]$ or $\left[\mathrm{mg} / \mathrm{m}^{3}\right]$, and according to the current standards, the concentration allowed is $0.5 \%$ from the indoor air [10].

The measurements were performed in a modular construction launched in a Start Up Nation project, through which several types of modular houses were proposed and constructed. The authors have contributed to the conception of these constructions. The tiny house is located in Podeni - Cluj County and has the floor plan represented in Fig. 1, respectively the vertical section presented in Fig. 2. 
Carmen Mârza, Georgiana Corsiuc, Dana Iluțiu-Varvara

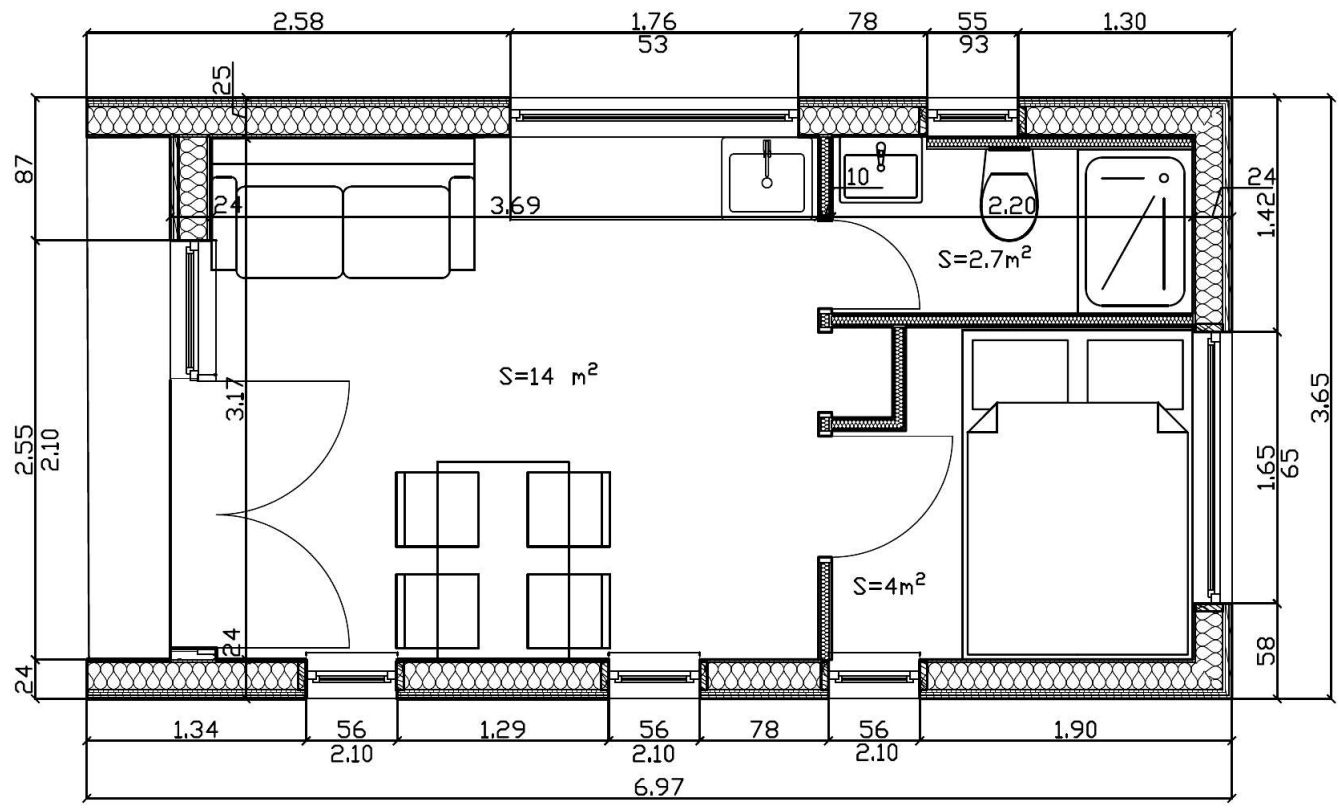

Fig. 1. Floor plan of the modular house

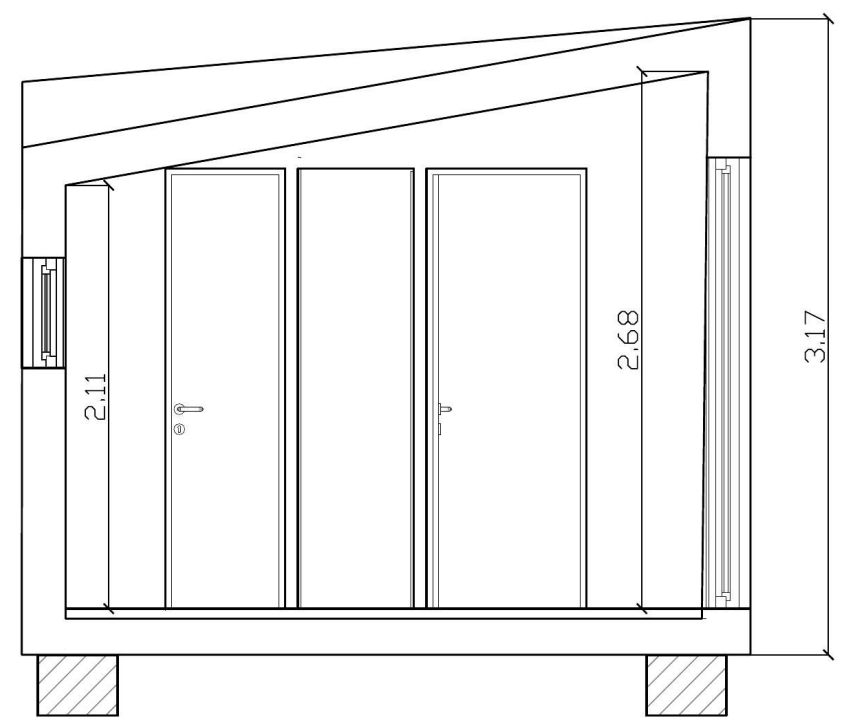

Fig. 2. Section of the modular house

The house is composed of 3 modules with a total living area of $19 \mathrm{~m}^{2}$, namely: a module that includes the bathroom and bedroom, and two modules are built for an open space for kitchen and living room and was designed as a holiday home serving 24 people.

In order to determine if the IAQ conditions are met in terms of $\mathrm{CO}_{2}$ concentration, it was established that measurements will be made in the bedroom during the night and in the living area during the day. Based on the plan and the section, the air volumes in the two rooms were calculated. 
Case Study Regarding the Evaluation of Carbon Dioxide in Modular Tiny Houses

From the vertical section can be observed that it has a trapezoidal shape, and the height regime differs in the bedroom area from leaving area. Thus, the volume inside resulted, and implicitly the volume of air, is $\mathrm{V}_{1}=10 \mathrm{~m}^{3}$ for the bedroom, respectively $\mathrm{V}_{2}=26 \mathrm{~m}^{3}$ for living and kitchen area.

The role of the measurements presented in the charts below is to determine whether the air quality requirements are met in a house with a small volume of air or whether additional methods are needed to ensure the necessary oxygen throughout 24 hours.

It was decided to perform measurements in the two spaces, knowing that the type of activity influences a person's breathing. Thus, in the bedroom we have reduced activity or rest type, while in the kitchen- living area we consider a normal activity.

The measurements were made using Netatmo Smart Indoor Air Quality Monitor, device which monitors the level of $\mathrm{CO}_{2}$, temperature, humidity and noise level at the same time. The $\mathrm{CO}_{2}$ meter has a range from 0 to $5000 \mathrm{ppm}$ and $\pm 50 \mathrm{ppm}$ accuracy (from 0 to $1000 \mathrm{ppm}$ ) or $\pm 5 \%$ (from 1000 to $5000 \mathrm{ppm}$ ). The house was occupied by two adults. During the measurements, the outside temperature had values between $12^{\circ} \mathrm{C}$ and $23^{\circ} \mathrm{C}$ through the day and between $8^{\circ} \mathrm{C}$ and $12^{\circ} \mathrm{C}$ through the night.

In a first phase, the concentration of $\mathrm{CO}_{2}$ was measured in the bedroom, during the night, with all the windows closed. The windows were closed from 20:00 to 07:00 when the house was ventilated by opening the windows. In order to have minimal heat loss during the cold season, the construction was very well insulated and hermetically sealed. For this reason, high values of the $\mathrm{CO}_{2}$ concentration can be observed in Fig. 3 .

The concentration of $\mathrm{CO}_{2}$ increased from $400 \mathrm{ppm}$ to $2800 \mathrm{ppm}$, far exceeding the recommended limit at the end of the night. ASHRAE standard, recommends that indoor $\mathrm{CO}_{2}$ concentrations to be below $700 \mathrm{ppm}$ to ensure human health [2],[12].

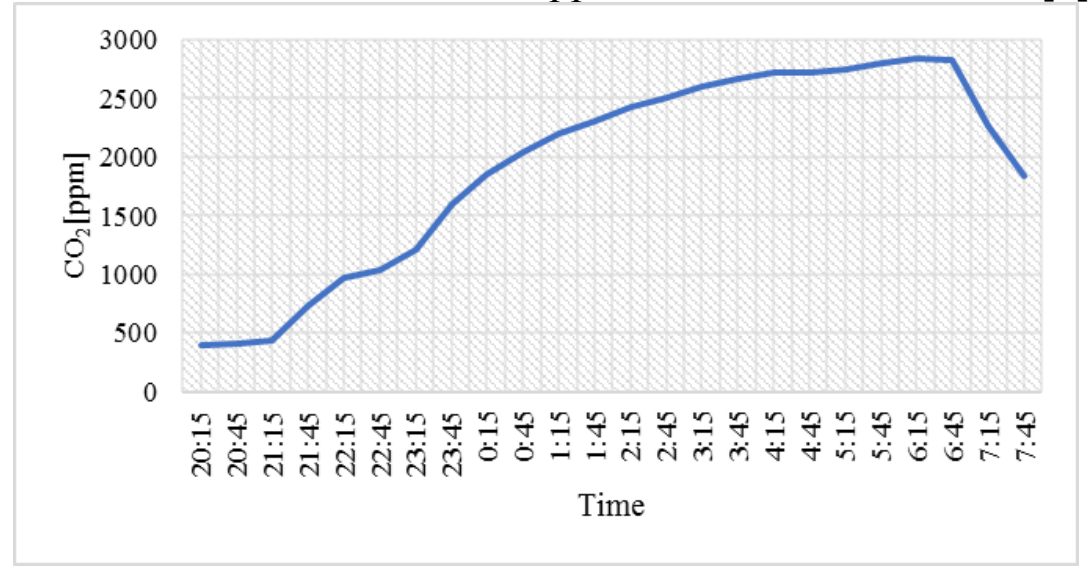

Fig. 3. $\mathrm{CO} 2$ concentration during the night - without ventilation

As a measure to reduce $\mathrm{CO}_{2}$ concentrations during the night, a window was left ajar in the living area with the door to the bedroom open, and the air quality was monitored again. Thus, as can be seen in Figure 4, the $\mathrm{CO}_{2}$ level remained within the comfort limit imposed by the standards. 
Carmen Mârza, Georgiana Corsiuc, Dana Iluțiu-Varvara

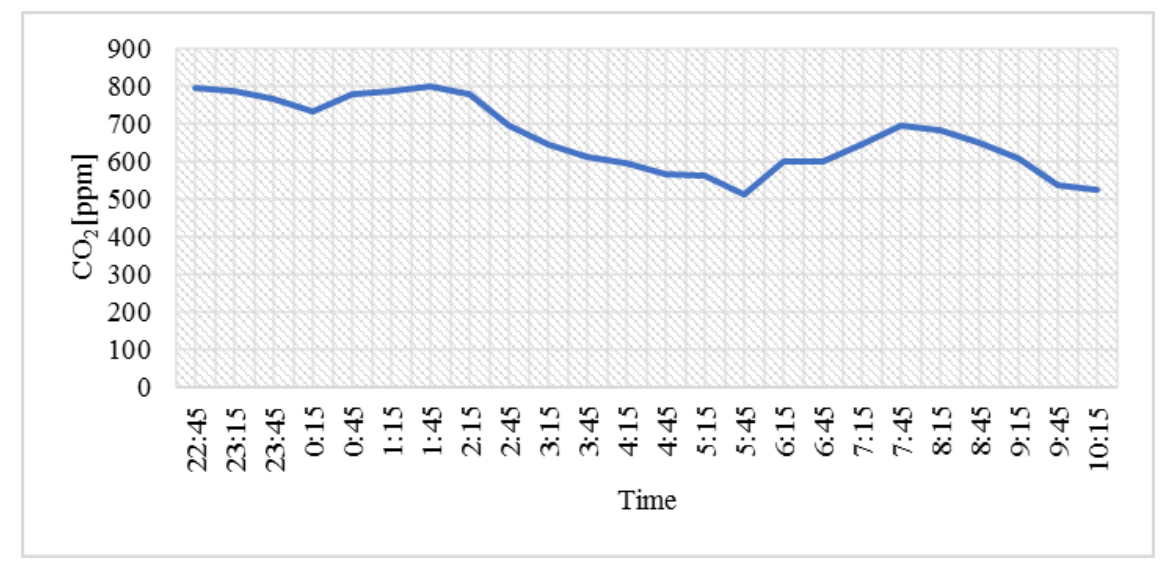

Fig. 4. $\mathrm{CO} 2$ concentration during the night - with open window

During the day, even if the measurements were made with the windows closed, the values of $\mathrm{CO}_{2}$ concentration are within the accepted limits due to the natural ventilation achieved by repeatedly opening the entrance door.

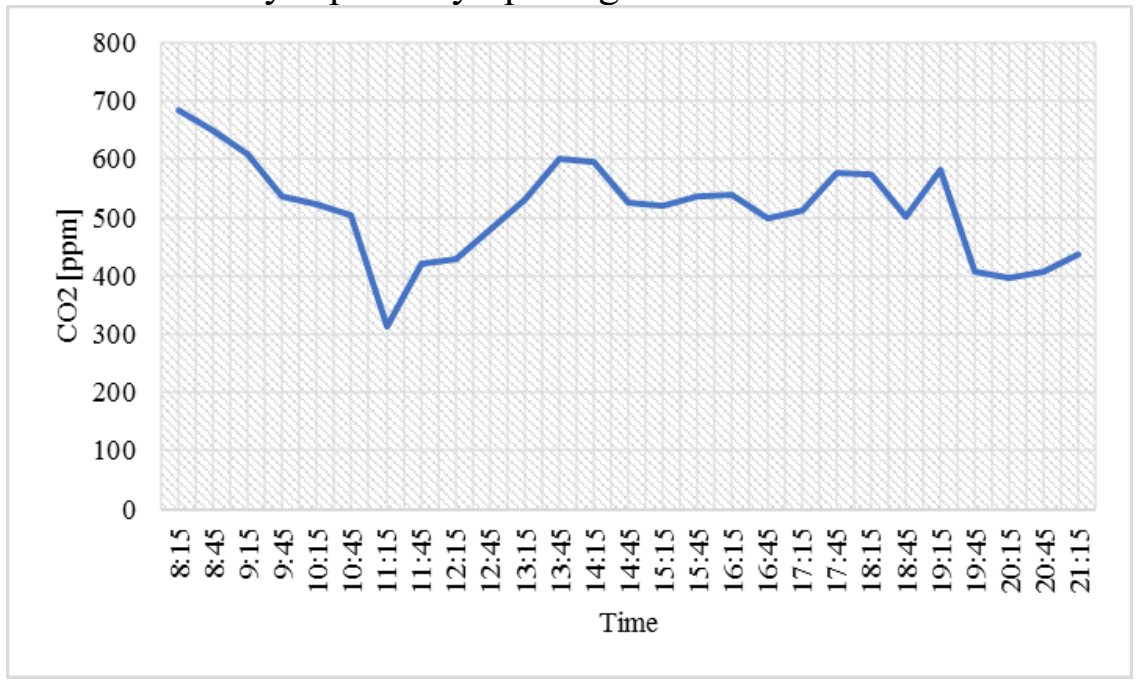

Fig. 5. $\mathrm{CO} 2$ concentration during the day

\section{Conclusions}

The measurements performed in the studied tiny house resulted in a series of conclusions presented below.

During the day, the measurements being performed in the living area, with a larger volume of air, even if the windows were closed, the values of the $\mathrm{CO}_{2}$ concentration were within the limits recommended by standards, respectively between 315 and $680 \mathrm{ppm}$. In this case, the fresh air was provided exclusively by opening the entrance door.

During the night, in the bedroom characterized by a smaller volume of air, when the ventilation was not achieved, the $\mathrm{CO}_{2}$ concentration exceeded the 
Case Study Regarding the Evaluation of Carbon Dioxide in Modular Tiny Houses

recommended limit, reaching values of $2800 \mathrm{ppm}$, which means that the air in the room is heavily contaminated, with negative effects on health. In this case, it is necessary to use a ventilation method. It was observed that, if the natural ventilation was achieved by leaving a window ajar, the values of $\mathrm{CO}_{2}$ concentration were within normal limits.

If natural ventilation is not sufficient or cannot be achieved due to extreme outside temperatures (very low or very high), to decrease the concentration of $\mathrm{CO}_{2}$, mechanical ventilation shall be used without reservation. For energy savings, it is recommended to use an automated ventilation system with heat recovery.

The final goal is to obtain constructions that meet the quality requirements provided by Law 10/1995, amended by Law 123/2007, which refers to: mechanical resistance and stability, fire safety, safety in operation, ensuring hygiene and health conditions, protection against noise, energy saving in correlation with the appropriate thermal insulation of the envelope, durability and easy maintenance. Also, these constructions must integrate perfectly with the environment, without having negative effects on it.

Complaints about lack of oxygen are generally unfounded, as the amount of oxygen in the air does not fall below $16 \%$ of the room volume, which does not affect the feeling of comfort. However, there are also places where the $\mathrm{CO}_{2}$ concentration is too high, frequently exceeding the maximum allowed, which requires air freshening measures.

\section{References}

[1] Mârza, C., Corsiuc, G., Graur, A.M.: Study on modular houses design, Journal of Industrial Design and Engineering Graphics, Vol. 14, Issue 1 (2019).

[2] ASHRAE, Calitatea aerului din interiorul clădirilor rezidențiale. Ghid. Practici optime pentru proiectarea, construcția, exploatarea și întreținerea locuințelor (Indoor Air Quality Guide : Best Practices for Design, Construction and Commissioning), Matrix Rom (2021).

[3] Mârza, C., Calitatea aerului - componentă fundamentală a confortului (Air quality - main component of comfort), Simpozionul Naţional Ştiinţa modernă şi energia - Producerea, transportul şi utilizarea energiei, Cluj-Napoca (2000).

[4] Mârza, C., Corsiuc, G, Despre relaţia confort ambiental - calitate a aerului - permeabilitate la aer a construcţiilor (About the relation between indoor comfort - air quality - air permeability of envelope), Romanian Journal of Civil Engineering, Vol. 8, Nr. 3, MatrixRom (2017).

[5] https://www.eea.europa.eu/ro/semnale/semnale-de-mediu-2013/articole/calitatea-aerului-din-interior.

[6] Recknagel, Sprenger, Honmann, Schramek, Le Recknagel, Manuel practique du genie climatique, PYC (2001).

[7] https://www.scienceinschool.org/ro/content.

[8] Fanger, $P$., $O$., Impact of temperature and humidity on perception and emission of indoor air polluants, DKV - Tagungsbericht 23 Jahngang, Leipzig (1994).

[9] Collection des guides de l'AICVF, Principes de l'aeraulique appliques au genie climatique, PYC Edition (2014).

[10] https://www.ergonomos.ro/sites/default/files/data/files/calitatea-aerului-interior.pdf.

[11] Andreieff de Notbeck, Manuel de conditionnement d'air, Pyc. Ed. (1986).

[12] Tran, V. V., Park, D., \& Lee, Y. C.: Indoor Air Pollution, Related Human Diseases, and Recent Trends in the Control and Improvement of Indoor Air Quality, International journal of environmental research and public health, 17(8), doi:10.3390/ijerph17082927 (2020). 